\title{
Kontrol Media Tiongkok di Era Xi Jinping sebagai Upaya Tiongkok menjadi Kekuatan Global
}

\author{
Esy Gracia \\ 2015330035 \\ Mahasiswa Ilmu Hubungan Internasional, Fakultas Ilmu Sosial dan Ilmu Politik \\ Universitas Katolik Parahyangan
}

\begin{abstract}
Abstrak
In the era of globalization, media is omnipresent as well as gaining more influence and importance. With the rise of digital platform, the role of media as an information provider is enhanced and could prevail people's political life. It is then clear that media is one of the pathways to become a Global Power due to its capability to direct public opinion. China in $X i$ Jinping's era, fully recognizing the media's potential, is continuing its effort on maintaining control over the media to be able to secure its prominence and level up its position in the international system. Using the concept of agenda setting and Uighurbiz website case as the example, this paper seeks to understand China's control over its media in order to ease their way to becoming a global power.
\end{abstract}

Keywords: China, media control, Uighurbiz, media as shaper, agenda-setting

\section{Pendahuluan}

\section{Relevansi Media dalam Politik}

Di era globalisasi dan era digital ini, media dan komunikasi menjadi semakin penting dan meningkat eksistensinya bagi manusia. Dimana pun seseorang berada, ia tidak akan bisa lepas dari media, baik berupa televisi, radio, koran, pemutar musik, telepon genggam, dan yang terutama, internet. Akibatnya, menjadi wajarlah jika media memiliki implikasi yang sangat signifikan pada budaya, masyarakat, dan tentu saja kehidupan politik (Hodkinson, 2011). Pertumbuhan yang cepat dari media ini telah membawa informasi politik ke khalayak umum sekaligus memberikan kesempatan bagi berbagai institusi dari seluruh spektrum politik untuk dapat secara cepat dan efektif menjangkau target audiences-nya (Lynch, 2011).

Riset telah membuktikan adanya hubungan yang positif antara penggunaan media dan partisipasi serta pengetahuan di bidang politik (Dimitrova, 2011). Sejalan dengan pandangan ini, Matthew Lynch menyatakan bahwa jika pemerintah dapat

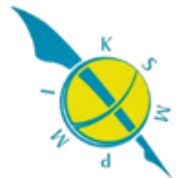


mengontrol semua informasi terkait seluruh tindakannya, hampir menjadi pasti bahwa segala upaya untuk mempertanyakan akuntabilitas pemerintah dapat dihindari dan pemerintah akan dapat memiliki tingkat pengaruh yang sangat tinggi terhadap tindakan masyarakatnya. Ditambah lagi, kini bahkan banyak organisasi besar dan berpengaruh yang memihak kepada aktor politik tertentu dengan implikasi menciptakan bias pada konten maupun cakupan, hingga menjadi alat propaganda virtual. Aktor dominan dalam media ini memiliki aset media yang besar dan dapat secara aktif mempengaruhi opini publik (Lynch, 2011).

\section{Kontrol Media Tiongkok dan Dinamikanya}

Sadar dengan potensi besar dari media di bidang politik ini, Tiongkok sebagai negara dengan ideologi komunis selalu menjaga kontrol terhadap media. Kontrol terhadap media di Tiongkok memang sudah ada sejak dulu, namun kebebasan pers yang tadinya sudah sedikit terlihat kini kembali ditekan. Sebagai buktinya, menurut Aljazeera, Tiongkok mengalami dua kali kondisi pers yang lebih longgar daripada biasanya, yaitu sebelum peristiwa protes di lapangan Tiananmen pada tahun 1989, dan pada Olimpiade Beijing tahun 2008. Akan tetapi, pada rezim presiden Xi Jinping, "the fourth estate" ini kembali diperketat. Pada kunjungannya ke tiga media utama pemerintah Tiongkok, yaitu koran People's Daily, agensi berita Xinhua, dan lembaga penyiaran China Central Television (CCTV), Xi meminta kepada para editor dan reporter dari perusahaan media tersebut untuk menjanjikan kesetiaan mutlak kepada Partai Komunis serta berkiblat pada kepemimpinan presiden dalam hal ide, pandangan politik, dan tindakan. Xi mengakui media-media tersebut adalah sendi dari propaganda pemerintah dan sudah seharusnya merefleksikan keinginan, otoritas, dan kesatuan dari partai (The guardian, 2016). Proses sensor pun tak ragu-ragu dilakukan pemerintah Tiongkok untuk mempertahankan mandat ini. Misalnya saja, respon yang mengkritisi pencabutan batas masa jabatan Xi Jinping yang membuatnya dapat menjadi presiden selama partai menunjuknya berhasil dibendung dan tidak pernah masuk ke media

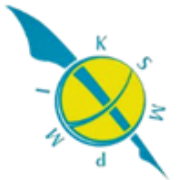


mainstream di Tiongkok. Justru, yang banyak ditonjolkan adalah berbagai pujian atas kepemimpinan Xi dan pentingnya Xi bagi Tiongkok (Aljazeera, 2011).

Meskipun demikian, media di Tiongkok tidak notabene menjadi statis. Hampir tiga perempat milyar warga Tiongkok menggunakan internet secara instensif. Meskipun Twitter dan Facebook dilarang di Tiongkok, platform yang serupa yaitu Sina Weibo, memiliki jumlah pengguna lebih banyak daripada pengguna Twitter di dunia, yaitu sejumlah 340 juta jiwa. Melalui platform seperti inilah kritik politik muncul. Selain itu, muncul pula gelombang media entrepreneurship di Tiongkok, yaitu penggunaan media secara privat atau "selfmedia". Seperti YouTube bagi dunia barat, ruang media Tiongkok kini sudah diwarnai dengan public figures yang menggunakan media sosial seperti Miaopai dan WeChat untuk mengadakan talk show dengan konten yang tidak dimuat di media milik pemerintah. Misalnya "The Papi Show" oleh Papi Jiang yang menyuarakan tentang norma gender yang sebenarnya berseberangan dengan nilai yang dianut Partai Komunis Tiongkok (Repnikova dan Fang, 2016). Semangat entrepreneurship dalam media inilah yang kemudian juga mendorong adanya situs seperti Uighurbiz.net, situs yang mengupayakan rekonsiliasi kaum Uighur dan rakyat Tiongkok di Xinjiang, yang menjadi contoh kasus dalam tulisan ini.

\section{Media sebagai Shaper dan Konsep Agenda-Setting}

Ada dua konsep yang dapat digunakan untuk mengkaji kontrol media Tiongkok di Era Xi Jinping sebagai Upaya Tiongkok Menjadi Kekuatan Global. Pertama adalah peran media sebagai shaper yang digunakan untuk menggambarkan kapabilitas media yang membuatnya dapat sangat berpengaruh pada politik sehingga dinilai sangat penting dan harus dikontrol. Kedua adalah konsep agendasetting yang akan mengilustrasikan bagaimana Tiongkok melakukan kontrolnya terhadap media.

Media dalam perannya sebagai shaper atau pembentuk dipercaya memiliki kapabilitas untuk mempengaruhi orang dan akhirnya membentuk masyarakat

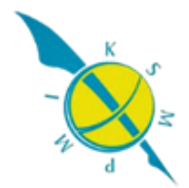


melalui konten yang didistribusikannya. Dalam kehidupan sehari-hari misalnya, penggambaran media terakit kekerasan dapat membuat seseorang menjadi waspada atau jika media menggambarkan sesuatu dengan positif, masyarakat juga akan memandang hal tersebut sebagai hal yang positif dan diterima, seperti contohnya kampanye "dua anak lebih baik". Pengaruh bahkan bias seperti ini pun dapat terjadi tidak hanya pada dimensi moral sehari-hari namun juga pada ranah politik. Media dapat menggeser ide di masyarakat dan menggiring opini publik. Sebagai contoh, media dapat sangat mungkin mengubah preferensi publik dalam memilih calon pemimpin dengan "mengiklankan" kebaikan dan pandangan-pandangan calon tersebut secara positif. Lebih besarnya lagi, media sangat mungkin memperkenalkan demokrasi sebagai ideologi yang baik hingga akhirnya membuat masyarakat menuntut demokrasi pada pemerintahan yang, sebut saja, komunis. Adapun peran media sebagai shaper ini dalam konteks linear, yaitu media mempengaruhi masyarakat dan bukan saling mempengaruhi. (Hodkinson, 2011).

Selain peran media sebagai shaper, konsep lain yang akan diangkat dalam tulisan ini adalah agenda-setting. Karakteristik agenda-setting meliputi adanya pemilihan topik yang cocok diangkat sebagai berita, memiliki tujuan untuk menentukan apa yang harus diperhatikan oleh publik, dan alterasi konten yang digunakan sebagai cara untuk memenuhi tujuan tersebut. Agenda-setting ini sendiri bisa dikatakan sebagai proses politik dengan media massa sebagai alat untuk membuat permasalahan sosial menjadi isu publik (Dearing dan Rogers, 1996).

Model agenda-setting menurut Dearing dan Rogers mengandung tiga komponen utama, yaitu agenda media, agenda publik, dan agenda kebijakan. Agenda publik adalah isu yang dianggap penting oleh masyarakat dan diketahui dengan cara melakukan survei serta mempelajari gerakan masyarakat. Agenda media adalah isu yang paling banyak diliput oleh media dan diukur melalui cakupan media pada isu tertentu. Agenda kebijakan adalah isu yang ingin dimajukan oleh elit politik dan dapat diukur melalui tindakan politis seperti mengeluarkan kebijakan baru atau melakukan tindakan penanganan tertentu dengan melibatkan sejumlah

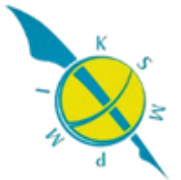


anggaran pada suatu isu. Adapun turut dikatakan bahwa tingkat kepentingan suatu isu dalam agenda media dapat meningkatkan tingkat kepentingan isu dalam agenda publik mengingat masyarakat akan lambat laun mengganggap suatu isu penting bagi publik karena intensitas pemberitaan suatu isu di media (Dearing dan Rogers, 1996).

\section{Kasus Uighurbiz.net}

Untuk memberikan gambaran konkret terkait kontrol media dalam politik Tiongkok di era Xi Jinping, esai ini akan merujuk pada contoh kasus situs Uighurbiz.net. Kasus ini dipilih karena kasus ini lahir dan memuncak pada era Xi Jinping, sekaligus dianggap sebagai salah satu kasus opresi pers media yang terbesar di Tiongkok menurut Committee to Protect Journalists (CPJ) hingga menyita perhatian internasional. Kasus ini pula lah yang menyumbang jumlah tahanan terbanyak dari 38 orang tahanan jurnalis di Tiongkok dan membuat Tiongkok berada dalam peringkat ke 176 dari 180 negara terkait indeks kebebasan pers yang dikeluarkan oleh grup Reporters Without Borders dari Perancis serta peringkat terakhir oleh Freedom House pada tahun 2017 (Xu dan Albert, 2017).

Uighurbiz.net adalah sebuah situs yang dibuat oleh Ilham Tohti, seorang ahli kaum Uighur yang paling terkenal di Tiongkok. Tohti menghabiskan dua puluh tahun berupaya untuk mengembangkan dialog antara kaum Uighur, etnis minoritas muslim yang tinggal di Timur Laut Xinjiang, dengan warga Tiongkok terkait persoalan sosial Uighur. Upayanya untuk merekonsiliasi kedua pihak ini membuatnya harus mendekam di penjara seumur hidup setelah nasibnya dibicarakan dalam pengadilan selama dua hari. Tohti mengambil studi minoritas di Central Minzu University di Beijing dan sebagai akademisi ia seringkali menyuarakan kritik terkait diskriminasi di Xinjiang. Ia pernah ditangkap polisi pada tahun 2009 karena mempublikasikan penangkapan, pembunuhan, dan hilangnya kaum Uighur. Tohti telah diawasi sejak tahun 1994 dan dilarang untuk mengajar maupun mempublikasikan karya di media utama Tiongkok sejak 1999. Pada era Xi

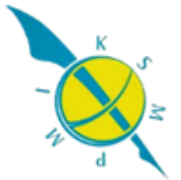


Jinping, tepatnya tahun 2014, penolakkan dan kontrol terhadap aktivitas Tohti memuncak dengan penutupan situs Uighurbiz.net serta pemenjaraan dirinya dan 15 kontributor lainnya. Tohti didakwa dengan tuduhan separatisme dan melawan negara serta menyebarkan ide tersebut kepada murid-muridnya (CPJ, 2016). Atas upayanya Tohti memenangkan Barbara Goldsmith "Freedom to Write” Award dari the PEN America Center pada tahun 2014, dan the Martin Ennals Award kategori pelindung HAM pada tahun 2016. Ia juga memperoleh nominasi pada European Parliament's Sakharov Prize untuk kebebasan berpikir pada tahun yang sama. Yang terakhir, Tohti menerima Human Rights Award dari kota Weimar di Jerman pada tahun 2017 (Chinachange, 2017).

\section{Upaya Konkret Kontrol Media Tiongkok: Kasus Uighurbiz.net}

Berkaca pada kasus Uighurbiz.net dan kaitannya dengan kontrol media yang dilakukan oleh pemerintah Tiongkok di era Xi Jinping, peran media sebagai shaper dapat digunakan untuk menjelaskan alasan kontrol terhadap media menjadi penting. Terkait peran media sebagai shaper, pemerintah Tiongkok sangat memandang media memiliki kapabilitas untuk mempengaruhi publik yang dibuktikan dengan betapa kerasnya tindakan pemerintah kepada Uighurbiz dan kontributornya yang mempublikasikan kondisi kaum Uighur dan mengkritik pemerintah Tiongkok yang opresif. Ketakutan Tiongkok ini sebenarnya sangat beralasan mengingat tensi diantara kaum Uighur dengan Han Tiongkok sudah berlangsung sejak lama dan dapat dengan mudah menyulut pergolakan sosial hingga yang terburuk, keinginan untuk memisahkan diri serta aksi teror. Percaya akan peran media sebagai shaper, pemerintah Tiongkok takut bahwa media, dalam hal ini Uighurbiz, dapat membentuk pandangan di masyarakat bahwa tindakan pemerintah Tiongkok kepada kaum Uighur adalah negatif dan membuat masyarakat tergerak untuk lebih jauh membawa konflik internal ini ke panggung internasional demi menekan pemerintah Tiongkok. Hal ini Tiongkok lakukan demi menjaga stabilitas rezim di negaranya. Pasalnya, pemerintah Tiongkok melakukan berbagai

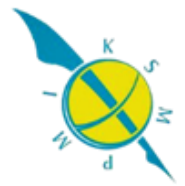


tindakan yang kontroversial, misalnya memasukkan kaum Uighur ke kamp detensi untuk menerima edukasi ulang (re-education) dimana mereka dikurung sampai entah kapan hanya karena orang-orang ini menjalankan kewajiban agamanya seperti salat yang "berlebihan" dan mengakses situs tertentu. Pada pusat-pusat pembelajaran ini, orang-orang Uighur, menurut Maya Wang, seorang ahli di Human Rights Watch, didoktrin untuk mencintai pemerintah Tiongkok dengan cara mempelajari prinsip-prinsip Tiongkok, mengembangkan semangat patriotik, dan mempelajari kebaikan Xi Jinping (Phillips, 2018).

Dengan penuh kesadaran bahwa media dapat mempengaruhi opini publik akan kasus Uighur, pemerintah Tiongkok pun tidak mau tinggal diam dan mengambil kontrol atas peristiwa ini. Kontrol tersebut dilakukan tidak hanya dengan menutup situs Uighurbiz dan menunjukkan bahwa Ilham Tohti menganut separatisme serta melawan negara, akan tetapi, pemerintah Tiongkok di era presiden $\mathrm{Xi}$ juga menggunakan dengan baik peran shaper media itu sendiri untuk menekankan pada publik bahwa langkah yang pemerintah Tiongkok lakukan adalah baik karena demi mengentaskan kelompok radikal islam. Hal ini digunakan untuk menjustifikasi tindakan Tiongkok. Seorang staf resmi di bidang propaganda kota Hotan, Bao Changhui, bahkan menyatakan kepada Associated Press (AP) bahwa langkah keras seperti ini perlu atau akan ada banyak nyawa yang hilang, seperti yang teradi pada tahun 2013 dan 2014 dimana terjadi sebuah penyerangan di stasiun kereta yang membunuh 33 orang (Shih, 2017). Dapat dilihat disini jika merujuk pada peran media sebagai shaper, pemerintah Tiongkok memiliki dua respon, yaitu dengan memastikan tidak ada media yang membentuk opini publik ke arah yang tidak diinginkan dan menggunakan media itu untuk membentuk sendiri opini publik ke arah yang mendukung pemerintah.

Terkait model dari agenda-setting, kasus Uighurbiz menunjukkan bahwa agenda kebijakan dalam hal ini menjadi komponen yang paling utama. Menampilkan tindakan keras pada Uighurbiz dan kontributornya sebagai sesuatu yang baik merupakan isu yang ingin dimajukan elit politik demi menjaga

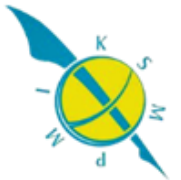


pandangan positif terhadap pemerintah. Pemerintah pun melakukan tindakan yang tentunya juga melibatkan sejumlah anggaran untuk menjaga majunya agenda ini, misalnya dengan melakukan sensor pada media privat, memastikan berita yang dipublikasikan memuat dukungan pada pemerintah, dan memastikan orang-orang yang berkaitan denga kasus Uighurbiz tidak melawan pemerintah. Dalam kasus ini, agenda media memiliki agenda yang sama dengan agenda kebijakan mengingat media itu sendiri dipegang kuat oleh pemerintah. Adapun komponen agenda publik dalam konteks Uighurbiz tidak mendapat sorotan. Hal ini dapat terjadi karena agenda publik kaum Uighur ditekan sepenuhnya oleh pemerintah Tiongkok dan warga Tiongkok lainnya bahkan tidak diekspos kepada permasalahan Uighurbiz secara komprehensif sehingga isu ini juga tidak dapat masuk ke agenda publik Tiongkok secara umum. Ditambah lagi, tidak ada upaya yang berhasil untuk meningkatkan kepentingan isu ini karena meskipun dikecam seperti apapun di kancah internasional, Tiongkok tetap kukuh dan selalu dengan waspada mengontrol opini publik rakyatnya yang mendukung pemerintah di platform manapun, termasuk di tengah meningkatnya arus media entrepreneurship sekalipun.

Dalam kasus ini, menjadi jelas bahwa dengan menggunakan peran media sebagai shaper dan dengan melakukan agenda-setting, Tiongkok pun menghilangkan gangguan yang dapat terjadi pada rezim. Dengan menghilangkan gangguan-gangguan tersebut, Tiongkok dapat berfokus pada aspek-aspek yang dapat membantunya menjadi kekuatan global, seperti mengembangkan ekonomi dan memperkuat militer.

\section{Kesimpulan}

Pemerintah Tiongkok pada era Xi Jinping sangat menyadari kemampuan media sebagai shaper dalam masyarakat. Hal ini memberikan Tiongkok alasan untuk memperketat pengawasannya pada media dan selalu berusaha memegang kontrol atas opini publik. Dalam kasus Uighurbiz, usaha kontrol ini dilakukan dengan menutup media yang mempublikasikan pandangan yang berseberangan

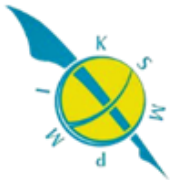


dengan pemerintah dan memberitakan tindakan pemerintah terkait hal ini sebagai sesuatu yang dibutuhkan, baik, dan urgen.

Secara lebih jauh, kontrol juga dilakukan dengan cara agenda-setting. Pemerintah dengan jelas memiliki kontrol yang dibuktikan dengan dipilihnya berita yang menekankan tindakan pemerintah untuk melawan gerakan separatis dan membasmi akar terorisme, mengalterasi konten hingga tak memuat pandangan positif pada Ilham Tohti, dan mengarahkan perhatian publik jauh dari kekerasan maupun kamp detensi. Ditambah lagi, upaya kontrol ini semakin nyata dengan diangkatnya isu ini sebagai agenda kebijakan yang diikuti dengan agenda media, serta menjauhkannya dari agenda publik. Pada akhirnya, ditengah arus media entrepreneurship sekalipun, pemerintah Tiongkok tetap dapat mengontrol media dan bahkan menegaskan upaya kontrol tersebut pada media apapun.

Adapun semua usaha kontrol media yang dilakukan Tiongkok untuk mempengaruhi politik dan masyarakatnya ini dapat dilihat sebagai upaya Tiongkok untuk melancarkan jalannya menjadi kekuatan global. Pasalnya, dengan mengentaskan semua gangguan terhadap rezim, Tiongkok dapat menjadi satu suara dan lebih fokus dalam mengembangkan aspek-aspek seperti ekonomi dan militer yang membantunya menjadi hegemon.

\section{Daftar Pustaka}

\section{Buku}

Dearing, J. W., \& Rogers, E. M. (1996). Agenda-setting. Thousand Oaks, Calif: Sage.

Hodkinson, P. (2017). Media, culture and society: an introduction. London: Sage Publications Ltd.

Repnikova, M. (2017). Media politics in china. S.l.: cambridge univ press. Doi: https://doi.org/10.1017/9781108164474

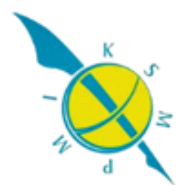




\section{Jurnal}

Dimitrova, D. V. (2014). The Effects of Digital Media on Political Knowledge and Participation in Election Campaigns: Evidence from Panel Data. Communication Research. DOI: 10.1177/0093650211426004

\section{Website}

2016 prison census: 259 journalists jailed worldwide. (2016, December 1). Retrieved March 12, 2018, from https://cpj.org/imprisoned/2016.php Aljazeera. (2018, March 05). Xi Jinping's power grab and China's media politics. Retrieved March 12, 2018, from https://www.aljazeera.com/programmes/listeningpost/2018/03/xi-jinpingpower-grab-china-media-politics-180303110448732.html

Associated Press. (2016, February 19). Xi Jinping asks for 'absolute loyalty' from Chinese state media. Retrieved March 12, 2018, from https://www.theguardian.com/world/2016/feb/19/xi-jinping-tours-chinas-topstate-media-outlets-to-boost-loyalty

Hashad, D. (2012). American News Coverage of Chinese Uighurs. Oxford Handbooks Online. doi:10.1093/oxfordhb/9780195395068.013.0032

Lynch, E. M. (2011, November 11). Analyzing the Media's Role in the Political Process. $\quad$ Retrieved March 12, 2018, from https://www.huffingtonpost.com/matthew-lynch-edd/analyzing-the-mediasrole_b_1083914.html

Phillips, T. (2018, January 25). China 'holding at least 120,000 Uighurs in reeducation camps'. Retrieved March 13, 2018, from https://www.theguardian.com/world/2018/jan/25/at-least-120000-muslimuighurs-held-in-chinese-re-education-camps-report

Posts about Uighurbiz on China Change. (n.d.). Retrieved March 12, 2018, from https://chinachange.org/tag/uighurbiz/

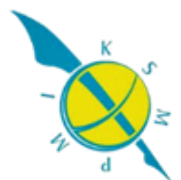


Shih, G. (2017, December 17). China's Uighur minority shackled by digital technology as thousands are detained for 'vocational training'. Retrieved March 12, 2018, from http://www.independent.co.uk/news/world/asia/thousands-china-xinjianguighur-beijing-disappear-fears-authorities-thought-police-personal-safetya8115421.html 